\title{
TINGKAT KEPUASAN PETANI KOPI TERHADAP KINERJA AGEN PEMASAR NEGRI KOPI SARONGGE
}

\author{
Oleh: \\ Hanisa Sismaya Lestari*) \\ Dewi Putri Anggraeni**) \\ Endah Lisarini*) \\ Nurjaya*) \\ Email : $\underline{\text { hanisasismaya@unsur.ac.id }}$
}

\begin{abstract}
ABSTRAK
Indonesia berada pada urutan ke-6 sebagai negara konsumsi kopi terbesar di dunia. Hal ini akan berbanding lurus dengan peningkatan areal perkebunan kopi dan produksi kopi. Sekitar 94,5\% produksi kopi di Indonesia dipasok dari pengusaha kopi perkebunan rakyat. Tingginya minat petani untuk menanam kopi, maka dalam hal pemasarannya perlu adanya agen pemasar. : Negri Kopi Sarongge merupakan salah satu agen pemasar dari para petani kopi ceri.Penelitian ini memiliki tujuan untuk mengkaji tingkat kepuasan Petani Kopi terhadap kinerja Agen Pemasar Negri Kopi Sarongge. Penelitian ini menggunakan metode Penelitian Analisis Deskriptif Kuantitatif, CSI dan IPA dengan jumlah responden 40 petani kopi yang memasok hasil kopinya ke Negri Kopi Sarongge. Hasil penelitian menunjukkan terdapat beberapa keuntungan dan manfaat yang diperoleh petani kopi yaitu: Membantu dalam hal pemasaran, Mendapatkan modal awal, Membantu dalam memanfaatkan hutan milik pemerintah, dan manfaat lainnya. Hasil pengolahan data dapat disimpulkan bahwa Analisis Costumer Satisfaction Index (CSI) menunjukkan bahwa petani kopi merasa sangat puas terhadap kinerja Agen pemasar Negri Kopi Sarongge dengan perolehan nilai sebesar 89,96\% yang berada pada rentang 80\% < CSI $\leq$ 100\%. Sedangkan untuk analisis Importance Performance Analysis (IPA) diperoleh kesimpulan bahwa penilaian petani kopi terhadap kinerja Agen Pemasar secara keseluruhan yaitu 4.46 yang berada pada rentang 4,20-5,00 dinilai sangat penting oleh petani. adapun beberapa atribut yang dianggap sangat penting oleh petani kopi di daerah Kecamatan Pacet tetapi pelaksanaan kinerja yang dilakukan oleh Negri Kopi Sarongge masih kurang, sehingga perlu ditingkatkan lagi kinerjanya.
\end{abstract}

Kata kunci : Kopi, Kepuasan, Agen Pemasar, CSI dan IPA.

\begin{abstract}
Indonesia is ranked 6 th as the largest coffee consumption country in the world. This will be directly proportional to the increase in coffee plantation area and coffee production. About 94.5\% of coffee production in Indonesia is supplied from plantation coffee entrepreneurs. The bigh interest of farmers to grow coffee, then in terms of marketing there needs to be a marketer agent. : Negri Kopi Sarongge is one of the marketer agents of cherry coffee farmers. This study aims to review the level of satisfaction of Coffee Farmers to the performance of Sarongge Coffee Marketer Agents. This study uses quantitative descriptive analysis research method, CSI and IPA with the number

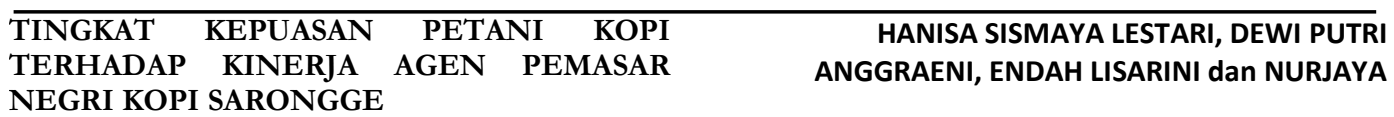


of respondents 40 coffee farmers who supply their coffee products to sarongge coffee country. The results showed there are several advantages and benefits obtained by coffee farmers, namely: Helping in terms of marketing, Getting initial capital, Helping in utilizing government-owned forests, and other benefits. The results showed there are several advantages and benefits obtained by coffee farmers, namely: Helping in terms of marketing, Getting initial capital, Helping in utilizing government-owned forests, and other benefits. The results of data processing can be concluded that costumer satisfaction index (CSI) analysis shows that coffee farmers are very satisfied with the performance of Sarongge Coffee Country marketer agent with a value gain of $89.96 \%$ which is in the range of $80 \%<C S I \leq 100 \%$. As for Importance Performance Analysis (IPA) was concluded that the assessment of coffee farmers to the overall performance of marketer agents is 4.46 which is in the range of 4.20-5.00 is considered very important by farmers. As for some attributes that are considered very important by coffee farmers in the district pacet but the implementation of performance carried out by the State Coffee Sarongge is still lacking, so it needs to be improved again performance.

Keywords: Coffee, Satisfaction, Marketer Agents, CSI and IPA.

*) Dosen Fakultas Sains Terapan UNSUR.

**) Alumni Fakultas Sains Terapan UNSUR. 


\section{PENDAHULUAN}

Indonesia merupakan negara agraris dengan kekayaan alam yang melimpah dan sebagian besar penduduknya bermata pencaharian sebagai seorang petani. Potensi sumber daya alam yang melimpah ruah ini merupakan suatu peluang dan modal dasar yang dapat dimanfaatkan untuk meningkatkan kesejahteraan masyarakatnya.

Adapun sektor pertanian mempunyai peranan yang cukup penting dalam kegiatan perekonomian di Indonesia. Hal ini dapat dilihat dari kontribusinya terhadap Produk Domestik Bruto (PDB) yang cukup besar, berdasarkan data yang diperoleh dari BPS (Badan Pusat Statistik) yaitu sekitar 13,14\% pada tahun 2017.

Menurut Habibullah (2018) yang merupakan Deputi Bidang Statistik Produksi, Salah satu sektor yang cukup besar potensinya adalah sub sektor perkebunan. Kontribusi sub sektor perkebunan dalam PDB yaitu sekitar 3,47\% pada tahun 2017 atau merupakan urutan pertama di sektor Pertanian, Perburuan, dan Jasa Pertanian. Sub sektor ini merupakan penyedia bahan baku untuk sektor industri, penyerap tenaga kerja, dan penghasil devisa.

Tanaman Kopi (Coffea spp.) merupakan salah satu komoditas hasil perkebunan yang mempunyai peranan yang cukup penting dalam kegiatan perekonomian di Indonesia karena mempunyai nilai ekonomis yang relatif tinggi di pasaran dunia. Kopi juga merupakan penghasil devisa negara selain minyak dan gas. Selain peluang ekspor yang semakin terbuka, pasar kopi di dalam negeri masih cukup besar.

Menurut data Statistik 2017, Perkebunan kopi di Indonesia dibedakan menjadi Perkebunan Besar (PB) dan Perkebunan Rakyat (PR). Perkebunan Besar terdiri dari Perkebunan Besar Negara (PBN), dan Perkebunan Besar Swasta (PBS). Perbandingan produksi kopi menurut status pengusahaan yaitu 2,17\% diproduksi oleh Perusahaan Perkebunan Negara, 2,37\% Perusahaan Perkebunan Swasta dan 95,46\% oleh Perkebunan Rakyat. Perkembangan luas areal perkebunan kopi menurut status pengusahaan tahun 2015 - 2017 disajikan pada Gambar 1.

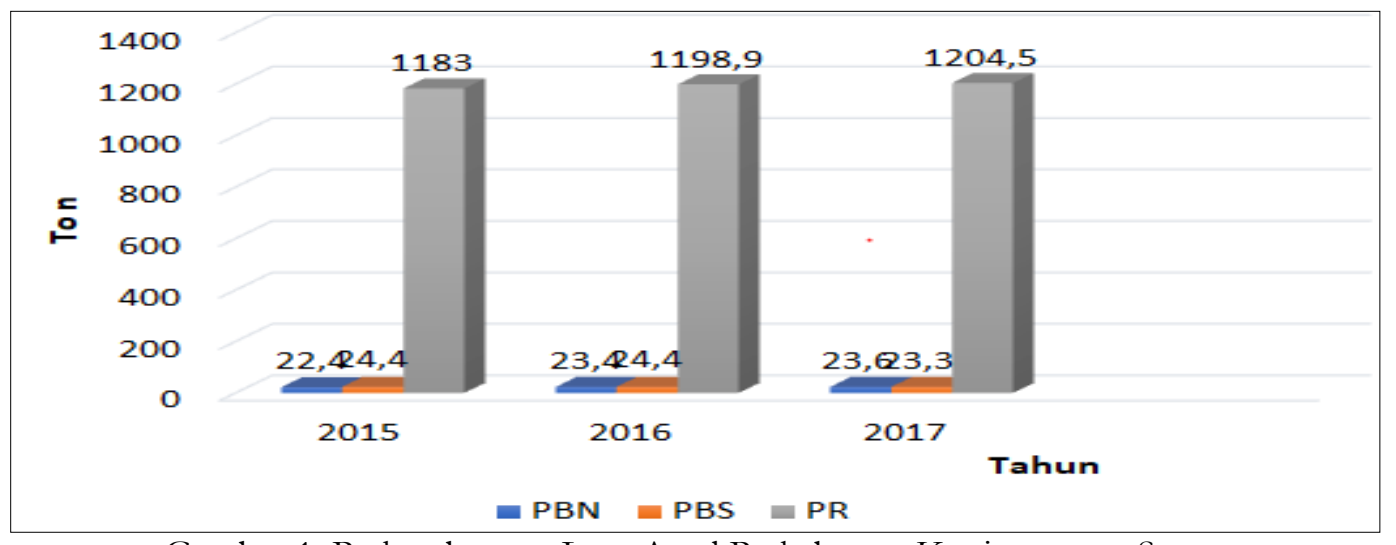

Gambar 1. Perkembangan Luas Areal Perkebunan Kopi menurut Status Pen-gusahaan (000 Ha), 2015-2017.

Sumber: Data Statistik 2017. 
Dalam gambar grafik diatas kita bisa melihat bahwa perkembangan luas areal perkebunan ini mengalami peningkatan dari tahun ke tahun meskipun ada yang tetap tapi tidak mengalami penurunan. Hal ini menandakan semakin banyaknya lahan yang dibuka untuk perkebunan kopi dan semakin banyak pula para petani ataupun pengusaha yang tertarik dalam bidang perkebunan kopi. Semakin meningkatnya luas areal kopi maka akan berbanding lurus dengan jumlah produksi kopi yang semakin meningkat pula. Perkembangan produksi kopi di Indonesia tahun 2015-2017 disajikan pada gambar 2 .

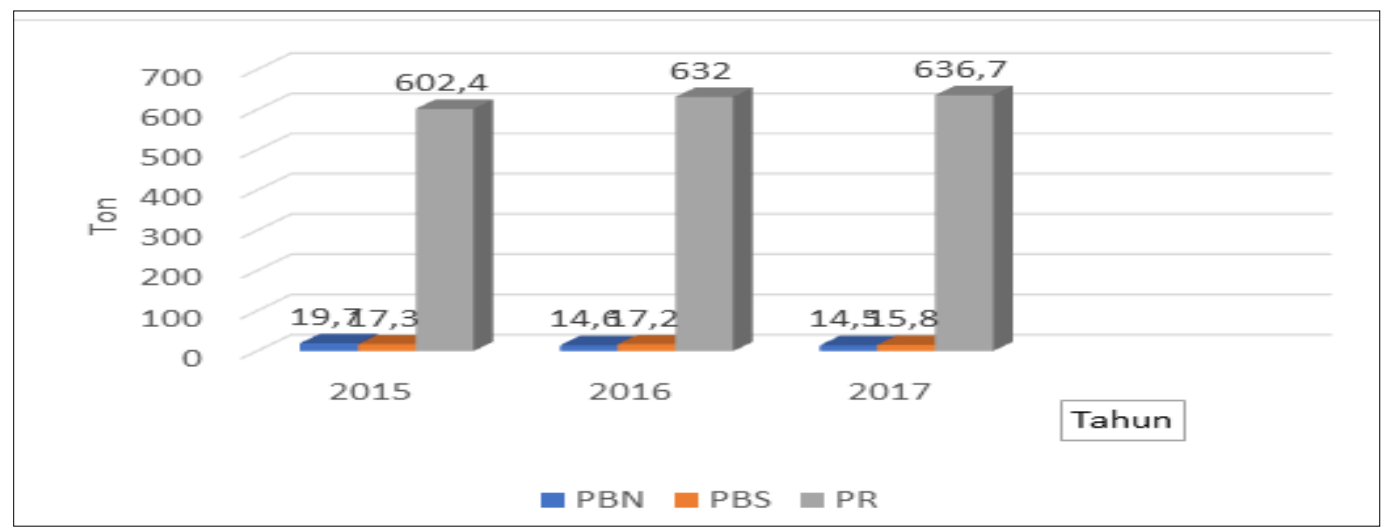

Gambar 2. Produksi Kopi di Indonesia Tahun 2015-2017* (000 Ton).

Sumber: Data Statistik 2017.

Apabila dilihat menurut provinsi, maka kontribusi terhadap total produksi terbesar dipegang oleh 5 Provinsi yaitu Sumatera Selatan 18,11\%, Lampung 17,44\%, Aceh 10,27\%, Sumatera Utara 9,90\%, Jawa timur 9,73\%. Jawa Barat berada diposisi ke Sembilan penghasil kopi terbesar di Indonesia dengan memproduksi kopi sebesar 19,602 ton pada tahun 2018.

Berdasarkan Pusat Data dan Sistem Informasi Pertanian Kementrian Pertanian, konsumsi kopi Nasional pada tahun 2016 mencapai sekitar 250 ribu ton dan tumbuh 10,54\% menjadi 276 ribu ton. Konsumsi kopi Indonesia sepanjang periode 20162021 diprediksi tumbuh rata-rata 8,22\% / tahun. Apalagi pada tahun 2021 mendatang, pasokan kopi diprediksi mencapai 795 ribu ton dengan konsumsi 370 ribu ton, sehingga menjadi surplus 425 ribu ton. Indonesia merupakan salah satu negara dengan konsumsi kopi terbesar di dunia. Data International Coffee Organization (ICO) mencatat konsumsi kopi Indonesia periode 2016/2017 mencapai 4,6 juta kemasan 60 $\mathrm{kg} / \mathrm{lb}(60 \mathrm{~kg})$ berada di urutan ke- 6 negara dengan konsumsi kopi terbesar di dunia.

Hal ini akan berbanding lurus dengan peningkatan areal perkebunan kopi dan produksi kopi. Sekitar 94,5\% produksi kopi di Indonesia dipasok dari pengusaha kopi perkebunan rakyat. Banyak nya minat petani untuk menanam kopi, maka dalam hal pemasarannya perlu adanya agen pemasar.

Agen pemasar adalah perusahaan-perusahaan yang berhubungan langsung dengan produsen dan bertugas sebagai perusahaan yang membantu menjual barang

\begin{tabular}{lcccr}
\hline TINGKAT & KEPUASAN & PETANI & KOPI & HANISA SISMAYA LESTARI, DEWI PUTRI \\
TERHADAP & KINERJA & AGEN & PEMASAR & ANGGRAENI, ENDAH LISARINI dan NURJAYA \\
NEGRI KOPI SARONGGE & & &
\end{tabular}


atau jasa tidak mempunyai hak kepemilikan atas semua barang yang dipasarkannya. (Mulyana,2019).

Dalam pemasarannya, kopi memiliki rantai pasok yang unik dan panjang, hal ini menyebabkan harga kopi sangat berbeda dari hulu ke hilir. Perbedaan kelengkapan alat serta ketersediaan jaringan yang dimiliki setiap tokoh merupakan beberapa alasan terbentuknya rantai pasok ini. Petani biasanya akan menjual hasil perkebunannya berupa ceri kopi ke pengepul ceri kopi yang memiliki alat dupler (Abduh,2008).

Petani kopi yang menjual ceri kopi ke agen pemasar salah satunya ke Negri Kopi Sarongge. Negri Kopi Sarongge adalah perusahaan yang didirikan oleh Bapak Tosca Santoso yang berada di Kampung Sarongge, Desa Ciputri, Kecamatan Pacet Cianjur, Jawa Barat. Negri Kopi Sarongge adalah tempat yang didirikan untuk menampung hasil panen kopi dari petani di wilayah Sarongge, dan juga merupakan tempat mengolah kopi yang mentah menjadi kopi matang berupa biji kopi ataupun sudah menjadi serbuk yang siap dipasarkan dan dikonsumsi.

Petani Sarogge akan menjual hasil perkebunannya ke Negri Kopi Sarongge yaitu berupa biji ceri kopi. Biji ceri kopi yang dibeli Negri Kopi Sarongge dari petani ini kemudian akan diproses dari mulai pencucian, pengeringan, penggilingan, pengemasan sampai distribusi dan bisa dikonsumsi langsung oleh konsumen. Hal ini mendorong penulis melakukan penelitian untuk mengetahui seberapa besar kepuasan petani kopi Sarongge ini dalam menerima layanan dari Negri Kopi Sarongge sebagai agen yang menerima, menampung, dan memasarkan kopinya.

\section{METODE PENELITIAN}

Pada penelitian ini tehnik yang digunakan adalah non-probability sampling dengan sample kuota. Sample kuota adalah Teknik untuk menentukan sampel dari populasi yang mempunyai ciri-ciri tertentu sampai jumlah (kuota) yang diinginkan (Sugiyono, 2017).

Teknik pengumpulan data yang digunakan dalam penelitian ini adalah sebagai berikut:

a. Observasi, adalah suatu proses yang didahului dengan pengamatan kemudia pencatatan yang bersifat sistematis, logis, objektif, dan rasional terhadap berbagai macam fenomena dalam situasi yang sebenarnya, maupun situasi buatan. (Kristanto,2018). Observasi juga dapat didefinisikan sebagai tehnik pengumpulan data dengan pengamatan, menulis, dan melakukan praktek langsung dilapangan. Observasi ini dilakukan langsung di tempat penelitian yaitu di Desa Ciputri, Kecamatan Pacet kepada Petani Kopi dan tempat usaha Negri Kopi Sarongge.

b. Wawancara, yaitu kegiatan mencari bahan (keterangan, pendapat) melalui Tanya jawab lisan dengan siapa saja yang diperlukan (Rianse, 2009). Menurut Yusuf (2014) wawancara juga dapat diartikan sebagai suatu kejadian atau suatu proses

\begin{tabular}{lcccr}
\hline TINGKAT & KEPUASAN & PETANI & KOPI & HANISA SISMAYA LESTARI, DEWI PUTRI \\
TERHADAP & KINERJA & AGEN & PEMASAR & ANGGRAENI, ENDAH LISARINI dan NURJAYA \\
NEGRI KOPI SARONGGE & & &
\end{tabular}


interaksi antara pewawancara (interviewer) dan sumber informasi atau orang yang diwawancarai (interviewee) melalui komunikasi langsung. Responden yang diwawancarai dalam penelitian ini adalah Petani Kopi di daerah sarongge yang menjual ceri kopi nya ke Negri Kopi Sarongge dan pemilik usaha Negri Kopi Sarongge yaitu Bapak Tosca Santoso dan Manager Pemasarannya yaitu Bapak Fachri.

c. Dokumentasi adalah metode pengumpulan data yang digunakan untuk menelusuri data histori. Dokumen tentang orang atau sekelompok orang, peristiwa, atau kejadian dalam situasi sosial yang sangat berguna dalam penelitian kualitatif (Yusuf, 2014). Tehnik dokumentasi juga dapat diartikan sebagai cara pengumpulan data melalui buku-buku tentang pendapat, teori, dan lain-lain yang berhubungan dengan masalah penelitian

d. Kuisioner, merupakan Teknik pengumpulan data dengan cara memberi seperangkat pertanyaan atau pernyataan tertulis kepada responden untuk menjawabnya (Sugiyono, 2010).

e. Studi Pustaka, adalah proses untuk mendapatkan sebuah informasi yang didapatkan dengan cara membaca arsip, buku serta jurnal-jurnal, dan penelitian terdahulu yang sesuai dengan penelitian ini.

f. Bimbingan, adalah tehnik pengumpulan data dengan cara diskusi bersama pembimbing lapangan untuk menyelaraskan bidang keilmuan yang didapat dibangku perkuliahan dengan sesuatu yang terjadi dilapangan.

Untuk menjawab tujuan penelitian ini maka dilakukan perhitungan Analisis Kuantitatif menggunakan Customer Satisfaction Index (CSI) dan Analisis Importance and Performance Analysis (IPA). Menurut Sugiyono (2016) metode kuantitatif dapat diartikan sebagai metode penelitian yang berlandaskan pada filsafat posivisme, digunakan untuk meneliti pada populasi atau sampel tertentu, teknik pengambilan sampel pada umumnya dilakukan secara random, pengumpulan data menggunakan instrument penelitian, analisis data bersifat kuantitatif atau statistic dengan tujuan untuk menguji hipotesis yang telah ditetapkan. Customer Satisfaction Index atau Indeks Kepuasan Konsumen merupakan sebuah metode yang menggunakan indeks untuk mengukur tingkat kepuasan konsumen. Konsumen dalam penelitian ini adalah Petani Kopi yang menjual ceri kopi kepada Negri Kopi Sarogge. Pengukuran terhadap indeks kepuasan pelanggan (CSI) diperlukan karena hasil dari pengukuran dapat digunakan sebagai acuan untuk menentukan sasaran-sasaran di tahun-tahun mendatang. (Listiawati, 2010).

\section{Analisis Importance and Performance Analysis (IPA)}

Rangkuti (2006) menyebutkan bahwa Importance and Performance Analysis (IPA) merupakan alat analisis tingkat kepentingan dan kinerja dari suatu produk/jasa. Analisa ini digunakan untuk menjawab permasalahan mengenai sejauh mana tingkat kepuasan petani terhadap pelayanan dari agen pemasaran. 
Menurut Ruhimat (2008) dalam Dalam analisis Importance and Performance Analysis (IPA) ini terdapat 20 atribut yang hendak diujikan, maka pengukuran menggunakan skala semantic differentials lima tingkat yang terdiri dari sangat penting, cukup penting, tidak penting dan sangat tidak penting. Menyebutkan bahwa penilaian setiap atribut yang akan menjadi bahan pertanyaan adalah sebagai berikut:

1. Jawaban sangat penting dibeli nilai 5

2. Jawaban penting diberi nilai 4

3. Jawaban cukup penting diberi nilai 3

4. Jawaban tidak penting diberi nilai 2

5. Jawaban sangat tidak penting diberi nilai 1

Tabel 1. Operasional Variabel penelitian.

\begin{tabular}{|c|c|c|c|}
\hline $\begin{array}{c}\text { Operasional } \\
\text { Variabel } \\
\text { Penelitian }\end{array}$ & Konsep Variabel & Indikator & Skala \\
\hline $\begin{array}{l}\text { 1. Berwujud } \\
\text { (Tangible) }\end{array}$ & $\begin{array}{l}\text { Tangibel merupakan Dimensi yang } \\
\text { menekankan kepada penampilan } \\
\text { fasilitas fisik penyedia jasa seperti } \\
\text { gedung, tersedianya tempat parkir, } \\
\text { kebersihan, kerapihan dan } \\
\text { kenyamanan ruangan, kelengkapan } \\
\text { peralatan komunikasi, dan } \\
\text { penampilan fisik dari personel } \\
\text { penyedia jasa. Kotler (2002) dalam } \\
\text { listiawati (2010) }\end{array}$ & $\begin{array}{l}\text { a. Peralatan selama } \\
\text { proses transaksi } \\
\text { b. Alat komunikasi yang } \\
\text { dimiliki oleh petugas } \\
\text { c. Tempat transaksi } \\
\text { yang bersih } \\
\text { d. Tempat transaksi } \\
\text { yang rapih } \\
\text { e. Tempat transaksi } \\
\text { yang nyaman }\end{array}$ & Ordinal \\
\hline $\begin{array}{l}\text { 2. Keandalan } \\
\text { (Reliabilit) }\end{array}$ & $\begin{array}{l}\text { Keandalan merupakan kemampuan } \\
\text { untuk memberikan pelayanan yang } \\
\text { telah dijanjikan dengan tepat } \\
\text { (accurately), kemampuan untuk } \\
\text { dapat dipercaya (dependably), serta } \\
\text { tepat waktu (on time). Kotler } \\
\text { (2002) dalam listiawati (2010) }\end{array}$ & $\begin{array}{l}\text { a. Menyampaikan } \\
\text { informasi kualitas } \\
\text { kopi yang diinginkan } \\
\text { konsumen kepada } \\
\text { petani } \\
\text { b. Kemampuan Agen } \\
\text { dalam membantu } \\
\text { memberikan solusi } \\
\text { atas keluhan petani } \\
\text { dalam hal pemasaran } \\
\text { kopi }\end{array}$ & Ordinal \\
\hline $\begin{array}{l}\text { 3. Kesigapa } \\
\mathrm{n} \\
\text { (Responsiv } \\
\text { eness) }\end{array}$ & $\begin{array}{l}\text { Kesigapan merupakan dimensi } \\
\text { yang menekankan kepada } \\
\text { kesediaan penyedia jasa dalam } \\
\text { membantu pelanggan dan } \\
\text { memberikan pelayanan yang sesuai } \\
\text { kebutuhan pelanggan secara cepat } \\
\text { dan tepat. Kotler (2002) dalam } \\
\text { listiawati (2010) }\end{array}$ & $\begin{array}{l}\text { a. Transaksi yang } \\
\text { dilakukan cepat } \\
\text { b. Tepat sasaran dalam } \\
\text { menyampaikan } \\
\text { edukasi kepada petani }\end{array}$ & Ordinal \\
\hline $\begin{array}{l}\text { 4. Kepastian } \\
\text { (Assuranc } \\
\text { e) }\end{array}$ & $\begin{array}{l}\text { Dimensi ini menekankan } \\
\text { kemampuan penyedia jasa untuk } \\
\text { membangkitkan keyakinan dan rasa } \\
\text { percaya diri pelanggan bahwa } \\
\text { penyedia jasa mampu memenuhi }\end{array}$ & $\begin{array}{l}\text { a. Mampu menampung } \\
\text { berapapun kopi yang } \\
\text { dihasilkan petani } \\
\text { b.Harga beli yang } \\
\text { pantas/sesuai }\end{array}$ & Ordinal \\
\hline
\end{tabular}




\begin{tabular}{|c|c|c|c|}
\hline $\begin{array}{c}\text { Operasional } \\
\text { Variabel } \\
\text { Penelitian }\end{array}$ & Konsep Variabel & Indikator & Skala \\
\hline & $\begin{array}{l}\text { kebutuhan pelanggannya. Meliputi } \\
\text { kemampuan karyawan atas } \\
\text { pengetahuan produk secara tepat, } \\
\text { keramah- tamahan, perhatian dan } \\
\text { kesopanan dalam memberikan } \\
\text { pelayanan, keterampilan dalam } \\
\text { memberikan informasi, serta } \\
\text { kemampuan dalam memberikan } \\
\text { keamanan di dalam memanfaatkan } \\
\text { jasa yang ditawarkan. karyawan atas } \\
\text { pengetahuan produk secara tepat, } \\
\text { keramah- tamahan, perhatian dan } \\
\text { kesopanan dalam memberikan } \\
\text { pelayanan, keterampilan dalam } \\
\text { memberikan informasi, serta } \\
\text { kemampuan dalam memberikan } \\
\text { keamanan di dalam memanfaatkan } \\
\text { jasa yang ditawarkan. Menurut } \\
\text { Kotler (2002) dalam listiawati } \\
\text { (2010) }\end{array}$ & $\begin{array}{l}\text { terhadap kopi yang } \\
\text { dibeli dari petani } \\
\text { c. Keakuratan saat } \\
\text { melakukan } \\
\text { penimbangan kopi } \\
\text { d. Ketepatan waktu } \\
\text { dalam membayar } \\
\text { kopi yang dibelinya } \\
\text { e. Melakukan } \\
\text { pembinaan kepada } \\
\text { petani } \\
\text { f. Mengajarkan cara } \\
\text { panen yang benar } \\
\text { kepada petani } \\
\text { g. Mengajarkan cara } \\
\text { menyimpan rapi } \\
\text { yang baik kepada } \\
\text { petani. }\end{array}$ & \\
\hline $\begin{array}{l}\text { 5. Empati } \\
\text { (Empathy) }\end{array}$ & $\begin{array}{l}\text { Empati adalah perhatian secara } \\
\text { individual yang diberikan } \\
\text { perusahaan kepada pelanggan } \\
\text { seperti, kemudahan untuk } \\
\text { menghubungi } \\
\text { kemampuan perusahaan, } \\
\text { berkomunikasi kepada pelanggan } \\
\text { dan urusan perusahaan untuk } \\
\text { memahami keinginan dan } \\
\text { kebutuhan pelanggan. Menurut } \\
\text { Kotler (2002) dalam listiawati } \\
(2010)\end{array}$ & $\begin{array}{l}\text { a. Kemudahan untuk } \\
\text { menghubungi Negri } \\
\text { Kopi Sarongge } \\
\text { b. Kemampuan } \\
\text { karyawan Negri Kopi } \\
\text { untuk berkomunikasi } \\
\text { dan melayani petani }\end{array}$ & Ordinal \\
\hline
\end{tabular}

\section{HASIL DAN PEMBAHASAN}

\section{Analisis Deskriptif Kuantitatif}

\section{Analisis Customer Satisfaction Index (CSI)}

Dari data yang telah diperoleh melalui pengisian kuisioner oleh setiap responden. Maka untuk mengukur tingkat kepuasan petani kopi di kecamatan Pacet secara keseluruhan dapat diukur dengan menggunakan analisis CSI (Customer Satisfaction Index). Tingkat kepuasan ini dihitung berdasarkan nilai rataan total dari tingkat kepentingan dan tingkat kepuasan. Hasil analisis kepuasan dapat dilihat pada tabel berikut: 
Tabel 2. Perhitungan Customer Satisfaction Index (CSI).

\begin{tabular}{|c|c|c|c|c|c|}
\hline NO & Variabel & MIS & MSS & WF & WS \\
\hline Ta1 & $\begin{array}{l}\text { Pihak Negri Kopi menggunakan peralatan selama } \\
\text { proses transaksi (kalkulator, buku, pena, alat timbang } \\
\text { dan lain-lain) }\end{array}$ & 4.55 & 4.58 & 0.049 & 0.223 \\
\hline $\mathrm{Ta} 2$ & $\begin{array}{l}\text { Pihak Negri Kopi menggunakan telpon seluler untuk } \\
\text { berkomunikasi saat transaksi }\end{array}$ & 4.23 & 4.50 & 0.045 & 0.204 \\
\hline Ta3 & $\begin{array}{l}\text { Pihak Negri Kopi melayani transaksi di tempat yang } \\
\text { bersih }\end{array}$ & 3.88 & 4.10 & 0.042 & 0.170 \\
\hline Ta4 & $\begin{array}{l}\text { Pihak Negri Kopi melayani transaksi di tempat yang } \\
\text { rapih }\end{array}$ & 3.85 & 4.13 & 0.041 & 0.170 \\
\hline Ta5 & $\begin{array}{l}\text { Pihak Negri Kopi melayani transaksi di tempat yang } \\
\text { nyaman }\end{array}$ & 3.98 & 4.25 & 0.043 & 0.181 \\
\hline Ry1 & $\begin{array}{l}\text { Pihak Negri Kopi menyampaikan informasi yang jelas } \\
\text { mengenai kualitas kopi }\end{array}$ & 4.50 & 4.65 & 0.048 & 0.224 \\
\hline Ry2 & $\begin{array}{l}\text { Kemampuan pihak Negri Kopi dalam membantu } \\
\text { memberikan solusi atas keluhan petani }\end{array}$ & 4.55 & 4.43 & 0.049 & 0.216 \\
\hline Ry3 & $\begin{array}{l}\text { Kemampuan pihak Negri Kopi dalam membantu } \\
\text { memberikan solusi dalam kegiatan pemasaran petani }\end{array}$ & 4.58 & 4.63 & 0.049 & 0.227 \\
\hline Rs1 & $\begin{array}{l}\text { Pihak Negri Kopi melakukan transaksi dengan cepat } \\
\text { (tidak menunda pembayaran) }\end{array}$ & 4.65 & 4.60 & 0.050 & 0.229 \\
\hline Rs2 & $\begin{array}{l}\text { Pihak Negri Kopi mampu menyampaikan dengan } \\
\text { tepat pengetahuan mengenai kopi kepada petani }\end{array}$ & 4.58 & 4.65 & 0.049 & 0.228 \\
\hline As1 & $\begin{array}{l}\text { Pihak Negri Kopi mampu menampung berapapun } \\
\text { banyaknya kopi yang dihasilkan oleh petani }\end{array}$ & 4.58 & 4.50 & 0.049 & 0.221 \\
\hline As2 & $\begin{array}{l}\text { Pihak Negri Kopi mampu menampung kualitas dari } \\
\text { semua jenis kopi }\end{array}$ & 4.53 & 4.50 & 0.049 & 0.218 \\
\hline As3 & $\begin{array}{l}\text { Pihak Negri Kopi membeli kopi dari petani dengan } \\
\text { harga yang sesuai pasar }\end{array}$ & 4.50 & 4.63 & 0.048 & 0.223 \\
\hline As4 & $\begin{array}{l}\text { Pihak Negri Kopi melakukan penimbangan kopi } \\
\text { secara tepat }\end{array}$ & 4.53 & 4.58 & 0.049 & 0.222 \\
\hline As5 & $\begin{array}{l}\text { Pihak Negri Kopi melakukan pembayaran dengan } \\
\text { tepat waktu kepada petani }\end{array}$ & 4.58 & 4.50 & 0.049 & 0.221 \\
\hline As6 & $\begin{array}{l}\text { Pihak Negri Kopi melakukan pembinaan terhadap } \\
\text { petani mengenai penanaman \& pemeliharaan tanaman } \\
\text { kopi }\end{array}$ & 4.53 & 4.33 & 0.049 & 0.210 \\
\hline As7 & $\begin{array}{l}\text { Pihak Negri Kopi mengajarkan cara panen yang benar } \\
\text { kepada petani }\end{array}$ & 4.65 & 4.65 & 0.050 & 0.232 \\
\hline As8 & $\begin{array}{l}\text { Pihak Negri Kopi mengajarkan cara penyimpanan kopi } \\
\text { yang baik kepada petani. }\end{array}$ & 4.53 & 4.60 & 0.049 & 0.223 \\
\hline Em1 & $\begin{array}{l}\text { Kemudahan dalam menghubungi } \\
\text { Sarongge }\end{array}$ & 4.28 & 4.30 & 0.046 & 0.197 \\
\hline Em2 & $\begin{array}{l}\text { Kemampuan pihak Negri Kopi dalam berkomunikasi } \\
\text { dengan petani }\end{array}$ & 4.63 & 4.58 & 0.050 & 0.227 \\
\hline Em3 & Kemampuan pihak Negri Kopi untuk melayani petani & 4.60 & 4.65 & 0.049 & 0.229 \\
\hline Total & & 93.23 & 94.30 & 1.000 & 4.498 \\
\hline \multicolumn{2}{|c|}{ Weight Average Total (WAT) } & 4.498 & & & \\
\hline \multicolumn{2}{|c|}{ Customer Satisfaction Index (CSI) } & \multicolumn{4}{|c|}{$89,96 \%$} \\
\hline
\end{tabular}

Sumber: Data Primer (diolah) 2020.

\begin{tabular}{lcccr}
\hline TINGKAT & KEPUASAN & PETANI & KOPI & HANISA SISMAYA LESTARI, DEWI PUTRI \\
TERHADAP & KINERJA & AGEN & PEMASAR & ANGGRAENI, ENDAH LISARINI dan NURJAYA \\
NEGRI KOPI SARONGGE & & &
\end{tabular}


Berdasarkan hasil perhitungan CSI yang dapat dilihat pada tabel di atas, diperoleh hasil yang menunjukkan bahwa nilai indeks kepuasan petani kopi terhadap kineja agen pemasar Negri Kopi Sarongge di Kecamatan Pacet berada pada rentang $80 \%<$ CSI $\leq 100 \%$ dengan perolehan nilai sebesar 89,96\%. Angka tersebut mengidentifikasikan bahwa secara umum petani kopi yang memasok ke Negri Kopi Sarongge merasa sangat puas terhadap kinerja yang diberikan oleh Negri Kopi Sarongge

\section{Importance Performance Analysis (IPA)}

Importance Performance Analysis (IPA) digunakan untuk mengukur tingkat kepuasan konsumen secara menyeluruh terhadap kinerja atribut-atribut agen pemasar negri kopi Sarongge dan hasil pengujian analysis IPA dapat dilihat pada gambar berikut.

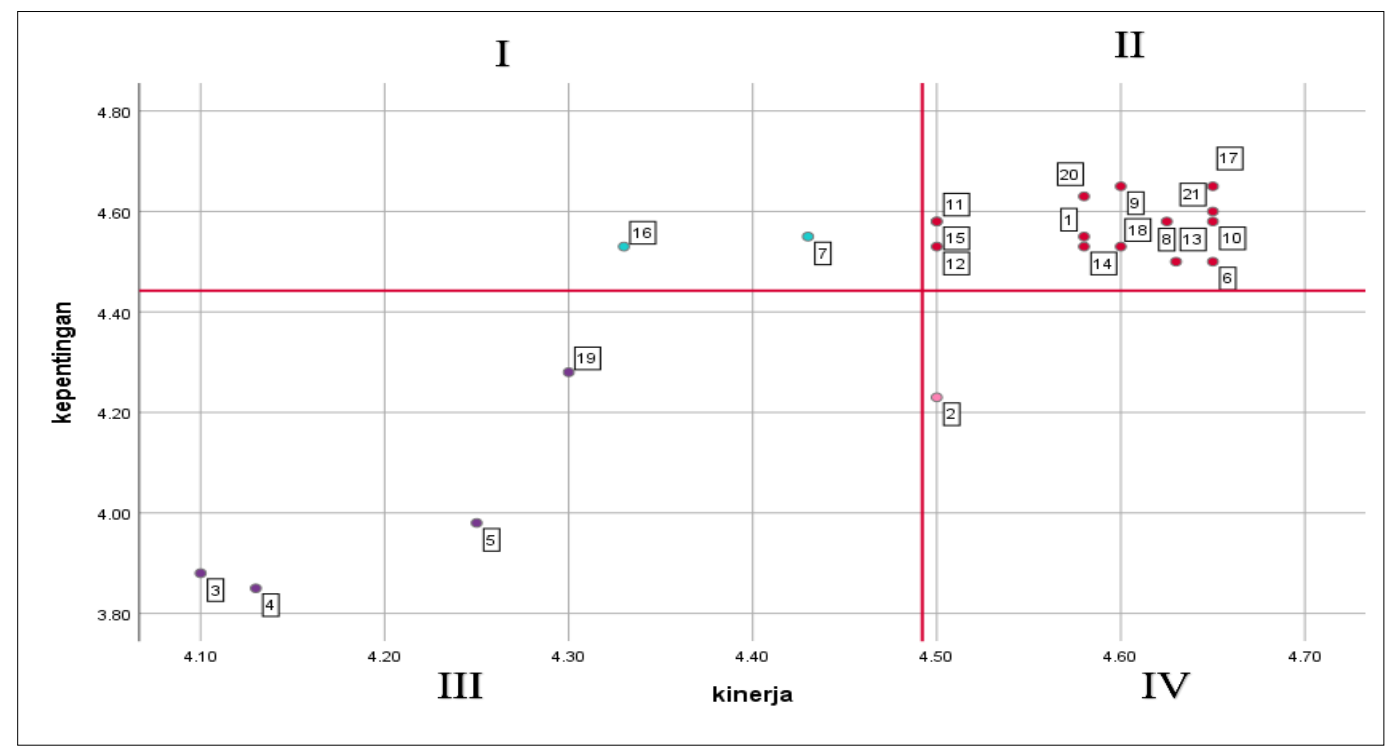

Gambar 3. Diagram Kartesius IPA kinerja Agen Pemasaran.

Dari gambar di atas dapat dilihat bahwa atribut-atribut dari kinerja agen pemasar negri kopi dari 1-21 atribut yang mempengaruhi kepuasan petani kopi terbagi ke dalam empat bagian yaitu kuadran I (Prioritas utama), kuadran II (Pertahankan prestasi), kuadran III (prioritas rendah), dan kuadran IV (berlebihan). Dari setiap atribut dalam kuadran ini memiliki makna dan perlakuan yang berbeda. Berikut penjelasan pada setiap kuadran.

\section{Kuadran I (Prioritas Utama)}

Atribut yang berada pada kuadran ini menunjukkan bahwa atribut-atribut tersebut dianggap sangat penting oleh petani kopi di kecamatan Pacet, tetapi kinerja yang dirasakan kurang memuaskan sehingga perlu adanya perbaikan agar harapan petani dapat terpenuhi. Beberapa atribut yang berada pada kuadran ini yaitu Kemampuan pihak Negri Kopi dalam membantu memberikan solusi atas keluhan petani (Ry2). Atribut tersebut berada pada kuadran ini karena menurut petani kopi 
solusi atas keluhan petani merasa belum tepat, tidak semua petani mampu mengambil resiko atas solusi yang diberikan seperti halnya keluhan terhadap kurangnya biaya operasional, solusi yang diajukan oleh pihak negri kopi yaitu dengan memberikan pinjaman kepada petani dengan waktu pengembalian selama 3 tahun, tetapi banyak petani yang mengeluh karena tidak berani mengambil resiko untuk meminjam uang. Atribut selanjutnya yang berada pada kuadran ini yaitu Pihak Negri Kopi melakukan pembinaan terhadap petani mengenai penanaman \& pemeliharaan tanaman kopi (As6). Atribut tersebut berada di kuadran ini karena petani merasa pembinaan yang dilakukan sangat penting untuk mendapatkan hasil yang memuaskan. Tetapi, pada praktiknya pembinaan ini tidak dilakukan secara berkala oleh Negri kopi sehingga petani-petani yang baru saja bergabung tidak merasakan pembinaan secara langsung.

\section{Kuadran II (Pertahankan prestasi)}

Atribut yang berada pada kuadran ini menunjukkan bahwa atribut-atribut tersebut dianggap penting oleh petani dan kinerja agen pemasar negri kopi dapat memuaskan petani, Beberapa atribut yang berada pada kuadran ini yaitu Pihak Negri Kopi menggunakan peralatan selama proses transaksi (kalkulator, buku, pena, alat timbang dan lain-lain) (Ta1), Pihak Negri Kopi melayani transaksi di tempat yang nyaman (Ta5), pihak Negri Kopi menyampaikan informasi yang jelas mengenai kualitas kopi (Ry1), kemampuan pihak Negri Kopi dalam membantu memberikan solusi dalam kegiatan pemasaran petani (Ry3), pihak Negri Kopi melakukan transaksi dengan cepat / tidak menunda pembayaran (Rs1), pihak Negri Kopi mampu menyampaikan dengan tepat pengetahuan mengenai kopi kepada petani (Rs2), pihak Negri Kopi mampu menampung berapapun banyaknya kopi yang dihasilkan oleh petani (As1), pihak Negri Kopi mampu menampung kualitas dari semua jenis kopi (As2), pihak Negri Kopi membeli kopi dari petani dengan harga yang sesuai pasar (As3), pihak Negri Kopi melakukan penimbangan kopi secara tepat (As4), pihak Negri Kopi melakukan pembayaran dengan tepat waktu kepada petani (As5). Atribut-atribut tersebut sudah sesuai dengan harapan petani dan petani merasa puas. Sehingga agen pemasar Negri Kopi harus dapat mempertahankan atribut kinerja pemasar pada kuadran ini.

\section{Kuadran III (Prioritas rendah)}

Atribut yang berada pada kuadran ini dianggap tidak terlalu penting oleh petani kopi dan kinerja agen pemasar kurang memuaskan, seperti Pihak Negri Kopi melayani transaksi di tempat yang bersih (Ta3), pihak Negri Kopi melayani transaksi di tempat yang rapih (Ta4), Pihak Negri Kopi melayani transaksi di tempat yang nyaman (Ta5) dan kemudahan dalam menghubungi Negri Kopi Sarongge (Em1).

\section{Kuadran IV (Berlebihan)}

Atribut yang berada pada kuadran ini dianggap tidak terlalu penting oleh petani tetapi kinerja nya memuaskan. Atribut yang berada pada kuadran ini yaitu pihak

\begin{tabular}{lcccr}
\hline TINGKAT & KEPUASAN & PETANI & KOPI & HANISA SISMAYA LESTARI, DEWI PUTRI \\
TERHADAP & KINERJA & AGEN & PEMASAR & ANGGRAENI, ENDAH LISARINI dan NURJAYA \\
NEGRI KOPI SARONGGE & & &
\end{tabular}


Negri Kopi menggunakan telpon seluler untuk berkomunikasi saat transaksi (Ta2). Hal ini karena petani biasanya langsung datang ke tempat untuk menjual hasil kopi nya tanpa menghbungi terlebih dahulu lewat telpon seluler, karena ada sebagian petani yang jarang memegang handphone.

Dari hasil di atas dapat disimpulkan bahwa terdapat atribut-atribut yang harus ditingkatkan kembali karena dianggap penting tetapi kinerja nya dirasa kurang memuaskan. Dalam pembahasan di atas sudah dijelaskan bahwa atribut yang dianggap penting tetapi kurang memuaskan yaitu Kemampuan pihak Negri Kopi dalam membantu memberikan solusi atas keluhan petani (Ry2) dirasa masih kurang tepat, Keluhan yang paling utama dirasakan adalah kurangnya biaya operasional. Padahal Negri kopi sudah memberikan solusi atas permasalahan yang dirasakan oleh petani. Namun, masalah yang muncul adalah tidak semua petani mampu mengambil resiko untuk meminjam uang karena masih merasa takut tidak bisa mengembalikan pinjaman tersebut dan tidak semua petani mengerti secara jelas system dari peminjaman tersebut. Sehingga yang perlu dilakukan oleh pihak agen pemasar Negri Kopi Sarongge adalah memberikan edukasi mengenai manajemen keuangan, mengubah persepsi petani terhadap solusi yang telah diberikan oleh Negri Kopi Sarongge dan memberikan edukasi Kembali kepada petani terkait system peminjaman uang.

Atribut yang kedua yaitu Pihak Negri Kopi melakukan pembinaan terhadap petani mengenai penanaman \& pemeliharaan tanaman kopi (As6). Dirasa belum memuaskan karena tidak dilakukan secara berkala. Keterbatasan petani mengenai budidaya kopi sehingga sering dijumpai berbagai kendala selama proses budidaya. Tentu saja permasalahan yang ditemui petani satu dan lainnya berbeda. Jika pihak Negri Kopi mendatangi petani satu persatu tidak akan efektif dan efisien. Hal yang perlu dilakukan oleh agen pemasar Negri Kopi Sarongge adalah memanfaatkan waktu ketika panen raya untuk sharing dengan para petani atas kendala mengenai penanaman dan pemeliharaan tanaman kopi.

Adapun atribut- atribut yang penting dan kinerja nya sudah memuaskan, maka agen pemasar Negri Kopi Sarongge harus mempertahankan kinerja nya.

\section{KESIMPULAN}

Dari hasil pengolahan data dengan menggunakan Analisis dari Customer Satisfaction Index (CSI) untuk mengetahui tingkat kepuasan petani kopi di daerah Kecamatan Pacet terhadap kinerja agen pemasar Negri Kopi maka diperoleh kesimpulan bahwa ada atribut yang dianggap sangat penting oleh petani kopi di daerah Kecamatan Pac0et tetapi pelaksanaan kinerja yang dilakukan oleh Negri Kopi masih kurang. 


\section{DAFTAR PUSTAKA}

Abduh (2008). Dari ITB untuk Indonesia: Biorefinery Kopi. Pusat Penelitian Biosains dan Bioteknologi Bandung. Institute Teknologi Bandung. Bandung

Badan Pusat Statistik. (2017). Statistik Kopi Indonesia. BPS Statistic Indonesia.

Kristanto, V. H. 2018. Metodologi Penelitian Pedoman Penulisan Karya Tulis Ilmiah (KTI). Malang: UB. Yogyakarta: CV Budi Utama.

Listiawati, Ika. (2010). Analisis Tingkat Kepuasan Petani Terhadap Kinerja Penyuluh Lapang di BP3K Wilayah Ciawi Kabupaten Bogor.Institut Pertanian Bogor. Bogor.

Mulyana, Mumuh. (2019). Strategi Distribusi. Universitas Terbuka. Bogor

Rangkuti, F. 2006. Measuring Costumer Satisfaction. Gramedia Pustaka Utama, Jakarta.

Rianse, Usman. (2009). Metodologi Penelitian Sosial dan Ekonomi. Edisi kedua. CV.Alfabeta.

Ruhimat, D. (2008). Kepuasan Pelanggan. PT. Gramedia Umum. Jakarta..

Sugiyono. (2010). Metode Penelitian Kuantitatif, Kualitatif, dan R\&D. Bandung: Alfabeta. - (2016). Metode Penelitian Kuantitatif, Kualitatif, dan R\&D. Bandung: Alfabeta.

(2017). Metode Penelitian Kuantitatif, Kualitatif dan R\&D. Bandung: Alfabeta.

Yusuf, A.M. (2014). Kuantitatif, Kualitatif \& Penelitian Gabungan. Jakarta: Kencana. 